\title{
Isolation and Characterization of Plant Growth Promoting Bacteria Isolated from Andean Soil as Potential Inoculants of Soybean Seeds
}

\author{
Carolina Belfiore $^{1}$, Ana P. Santos ${ }^{1}$, Manuel Contreras ${ }^{2} \&$ María E. Farías $^{1}$ \\ ${ }^{1}$ Laboratorio de Investigaciones Microbiológicas de Lagunas Andinas (LIMLA), Planta Piloto de Procesos \\ Industriales Microbiológicos (PROIMI-CONICET), Tucumán, Argentina \\ ${ }^{2}$ Centro de Ecología Aplicada (CEA), Suecia 3304, Ñuñoa, Santiago F56-2-2741872, Chile \\ Correspondence: María Eugenia Farías, Laboratorio de Investigaciones Microbiológicas de Lagunas Andinas \\ (LIMLA), Planta Piloto de Procesos Industriales Microbiológicos (PROIMI-CONICET), Tucumán, Argentina. \\ Tel: 54-381-434-4888. E-mail: mefarias2009@gmail.com
}

Received: July 2, 2018

doi:10.5539/enrr.v8n3p203
Accepted: July 26, 2018

URL: https://doi.org/10.5539/enrr.v8n3p203

\begin{abstract}
Argentina is the leading exporter of soybean oil and flour, and the third largest producer of grain. Since, the crop is a matter of great importance to the national economy. Their production depends on the soil as their main resource to ensure a good productive capacity, so it is necessary to preserve the physical, chemical and biological properties of the soil. Although, the indiscriminate use of chemical fertilizers, disturb them. In recent years, there has been a trend towards cleaner production to reduce the use of chemical. One of the alternatives involves biological means through the use of plant growth promoting bacteria. These group of bacteria colonize the rhizosphere of plants and stimulate the plant growth by several mechanisms.

The objective of this work was to characterize, identify and evaluate the growth promoting effect of 13 strains isolated from the Andean vegetation rhizosphere. The bacterial isolates were Enterobacteria, Stenotrophomonas, Pseudomonas, Nocardiodes, Bacillus, Exiguobacterium, Acinetobacter and Lactococcus genera. The results of the biochemical characterization determined that from the 13 bacterial strains, which produce siderophores, 11 possess the catalase enzyme, 10 fixate nitrogen, 12 produce the protease enzyme, 12 solubilize phosphorus, and 11 produce indoleacetic acid.

The application of different inoculums to the seeds, allowed to obtain plants with longer stem length, more developed roots, larger and more intense coloration leaves than the control plants. The results encourage deeper studies to achieve the formulation of inoculums to use as a biofertilizer, which would replace chemical fertilizers or reduce their doses.
\end{abstract}

Keywords: Andean Soil, Plant Growth Promoting Bacteria, Soybean Seeds

\section{Introduction}

Soil is an important natural resource that needs to be preserved and improved its quality and productive capacity (Pascual et al., 2000). It is considered a heterogeneous compound defined by its physical, chemical and biological properties, which in the environment maintains the interaction and dynamic equilibrium between its components. It is known that the performance of an edaphic ecosystem depends on a large extent of the microbial activity of the soil, since they play an important role in nutrient cycling (Paul \& Clark, 1996).

In recent years, there has been a trend towards clean production, which aims to reduce the use of chemical inputs for the fertilization and control of phytopathogens. Although, chemical fertilizers represent between $20-30 \%$ of the costs of production of a crop and when are properly used increase productivity and profitability, its indiscriminate use has a severe environmental impact. These Agrochemicals are involved in the alteration of the natural microbiota of the soil, reduce and significantly harm the beneficial interactions between the microorganisms and the plant.

The environmental problems are arising from the use of Agrochemicals and the continuous increase in their price; there is a need to look for new alternatives that reduce the fertilizer levels. However, such reductions could represent an abiotic stress on the plants. Hence, there is a need to develop new alternatives that do not damage the environment. One potential way to decrease the negative environmental impact involves biological methods 
because contribute to improve or maintain the soil quality and biodiversity (Abiala et al., 2015, Hungria et al., 2010, 2013; Adesemoye et al., 2009; Alves et al., 2004).

The term plant growth promoting rhizobacteria (PGPR) was first defined by Kloepper and Schroth (1978) to describe an heterogeneous group of soil bacteria that colonize the rhizosphere of plants, growing in, on or around plant tissues, which stimulate plant growth by several mechanisms (Ahmad et al., 2006; Pérez-Montaño et al., 2014).

The exact mechanisms by which PGPR promote plant growth, are not fully understood, but are thought to include (i) the ability to produce or change the concentration of plant growth regulators like indoleacetic acid, gibberellic acid, cytokinins and ethylene (Arshad \& Frankenberger, 1993; Glick, 1995), (ii) asymbiotic N2 fixation (Boddey \& Döbereiner, 1995), (iii) antagonism against phytopathogenic microorganisms by production of siderophores (Scher \& Baker, 1982), antibiotics (Shanahan et al., 1992) and cyanide (Fleishman et al., 1996), (iv) solubilization of mineral phosphates and other nutrients (De Freitas et al., 1997; Gaur, 1990). In the last years, the popularity of microbial inoculums has substantially increased (Berg 2009; Thakore 2006).

An "extreme" habitat is defined as an area where physical conditions are far from those optimal for human life. From a less anthropocentric point of view, volcanoes and geysers, marine depths, salt flats, deserts, ice and eternal snows, and alkaline lakes are considered extreme ecosystems while the microorganisms that colonize these environments are called "extremophiles" (Rothschild \& Mancinelli, 2001); they have adapted their genotypes and phenotypes to survive these unusual conditions, which are not "extreme" for them. For this reason, extreme microorganisms offer diverse potential applications in various fields of biotechnology.

Soybeans are also known as "Manchuria bean" or "China pea" that is an annual dicotyledonous herbaceous plant of the legume family (Fabaceae), subfamily Papilionoideae (L. Rapela 2013). These names have their origins in the areas of central and northern China and are characterized by their high protein content and nutritional quality. The soybeans occupy an intermediate position between pulses and oleaginous grains, contains more protein than most legumes and less fat than most oilseeds (Toledo, 2009). They are of great agricultural and industrial interest.

In Argentina, around 32 million hectares are planted with 17 million soybeans. It is the crop that has grown the most in the last 25 years and has a distinctive characteristic with respect to the other grains: it is exported almost entirely. Also, our country is the third world producer of soybeans with around 48 million tons, after the United States with 80 million, Brazil with 60 million and ahead of China with 18 million (FAO 2016).

The soybean crop is highly demanding and also is an extractive of nutrients. Because, it is the crop that produces more nitrogen, phosphorus, sulfurs and potassium extracts with each ton of grain (García, 1999). Therefore, most farmers tend to use fertilizers, improve soil quality, and increase production in their crops.

Nowadays, it is urgent to maintain that high productivity, but it is necessary to alter as little as possible the environment. Hence, the aims in this work were characterizing isolated bacteria from Andean soils and select those with plant growth promotion traits and finally study their effects on soybean.

\section{Materials and Methods}

\subsection{Sampling and Isolation}

The samples were taken in July 2015, from Tocorpuri Peatland, a place located in Second Region, Antofagasta, Chile. 596.149 E; 7.511.532 S.

For isolation, ten grams of soil material were rinsed with $90 \mathrm{~mL}$ phosphate buffer saline solution, followed by vortexing. Serial dilutions were prepared and spread plating on differential selective culture medium (AGEL, MLR, TSB and soil extract). The inoculated plates were incubated at $30^{\circ} \mathrm{C}$ for 7 days. After incubation, single colonies were subcultured onto fresh broth medium.

\subsection{Genotypic Characterization}

\subsubsection{DNA Extraction From Pure Cultures and 16S Rdna Gene Sequence Analysis}

Chromosomal DNA of the 13 isolates was prepared as described by Pospiech and Neumann (1995). The 16S rDNA was amplified using the primer set F27/R1492 (Lane 1991), see Table 1. Polymerase chain reaction (PCR) products were checked in $0.8 \%(\mathrm{w} / \mathrm{v})$ agarose gels, and DNA sequencing was performed by Macrogen (Korea).

Table 1. PCR Primers and amplification programs

\begin{tabular}{|c|c|c|c|c|c|}
\hline Primer & Sequence $\left(5^{\prime} \rightarrow 3^{\prime}\right)$ & Denaturing & Annealing & Extension & Cycles \\
\hline F27 & 5'AGAGTTTGATCMTGGCTCAG3' & \multirow{2}{*}{$94^{\circ} \mathrm{C}, 45^{\prime \prime}$} & \multirow{2}{*}{$53^{\circ} \mathrm{C}, 30^{\prime \prime}$} & \multirow{2}{*}{$72^{\circ} \mathrm{C}, 90^{\prime \prime}$} & \multirow{2}{*}{30} \\
\hline R1492 & 5'TACGGYTACCTTGTTACGACTT3' & & & & \\
\hline
\end{tabular}




\subsection{Characterization of Isolated as $P G P B$}

Experiments were performed in triplicate.

\subsubsection{Catalase Test}

The ability to produce catalase enzyme was tested. Place a small amount of overnight culture onto a clean microscope slide and a drop of hydrogen peroxide (5\%) was added. Positive reactions are evident by immediate effervescence (bubble formation).

\subsubsection{Production of Indole Acetic Acid (IAA)}

The method used for the quantitative and qualitative estimations in the determination of Indoleacetic Acid (IAA) was the Salkowski colorimetric technique.

The bacteria were grown in modified LB medium with $1 \mathrm{mg} / \mathrm{ml}$ of tryptophan (Atlas 1946) and were left under constant stirring at $150 \mathrm{rpm}$ for 72 hours at $30{ }^{\circ} \mathrm{C}$ to produce Indoleacetic acid (Sachsen 2009). Cultures were centrifuged at $5000 \mathrm{rpm}$ for $15 \mathrm{~min}$ followed by removing and mixing the supernatant with Salkowski's reagent in the ratio $4: 1$. The mixture was incubated at room temperature for $30 \mathrm{~min}$, and absorbance values were measured at $530 \mathrm{~nm}$, using of distilled water as a blank. This experiment was performed in triplicate.

The quantity of IAA produced by bacterial isolates was determined by comparing absorbance values with those from a standard curve. Pure IAA (Sigma-Aldrich Co.) was used to prepare standard concentrations of $0,2,4,6,8$, $10,15,20,40,50,60 \mu \mathrm{g} / \mathrm{ml}$.

\subsubsection{Phosphate Solubilization}

The phosphate solubilization was determined according to Vázquez et al., (2000), each pure culture was spread on Sundara Rao Sinha Medium (SRSM), specific medium that containing insoluble calcium phosphate. Plates were incubated at $30^{\circ} \mathrm{C}$ for $96 \mathrm{hrs}$. Phosphorus solubilizing strains were evidenced by the change in color of the indicator to yellow.

\subsubsection{Siderophore-Producing Strains}

The production of siderophores was tested in agar medium with chromium azurol sulfonate (CAS), according to the methodology of Louden BC (2011). Strains were grown in a minimal medium without iron source for 24 hours at $30^{\circ} \mathrm{C}$, and $200 \mathrm{rpm}$.

After 24 hours, $1 \mathrm{ml}$ of each culture was taken and centrifuged at $12.000 \mathrm{rpm}$ for $15 \mathrm{~min}$. From the cell-free supernatant, $35 \mu \mathrm{l}$ were taken and inoculated in each of the holes of the plate with the CAS-AGAR medium.

The plates were incubated 24 hours at $30^{\circ} \mathrm{C}$, the formation of orange haloes around the well indicating siderophore activity.

\subsubsection{Protease Production}

The protease production was determined according to Abo-Aba et al., 2006 with modifications. Plates were inoculated with $1 \mu \mathrm{L}$ of pure bacterial culture in a Petri dish containing $3 \%$ agar milk. Plates were incubated at 30 ${ }^{\circ} \mathrm{C}$ for 24 hours. The positive result was evidenced by the formation of transparent haloes around each colony.

\subsubsection{Nitrogen Fixing Activity}

The pure bacterial cultures were inoculated in plates with $\mathrm{Nfb}$ medium (Cadena \& Martinez, 2011), with $\mathrm{NH}_{4} \mathrm{Cl}$ as a unique nitrogen source. Plates were incubated $28 \pm 2{ }^{\circ} \mathrm{C}$ for 7 days; a color change from green to blue qualitatively indicates the positive effect of $\mathrm{N}_{2}$-fixing activity.

\subsection{Bacterial Growth and Seed Inoculation}

\subsubsection{Inoculum Preparation}

Thirteen strains isolated from Tocorpuri Vegas were used in this work. After incubation, the cells were centrifuged at $10,000 \mathrm{x}$ g for $10 \mathrm{~min}$ and washed three times with distilled water to remove any culture medium residue that may interfere with the growth promoting effect on soybean plants. Soybean seeds (Glycine Max 2000) were sterilized in surface with ethanol 3 times during $15 \mathrm{~min}$ and rinsed with distilled water 5 times. Later, the seeds were treated with the bacterial suspensions at the concentration of $10^{5} \mathrm{CFU} \mathrm{m} l^{-1}$ for 50 min to $200 \mathrm{rpm}$ under sterilized conditions. The control of seeds was realized soaking them with sterilized and distilled water.

\subsubsection{Pot Experiment}

The sterilization of the soil was carried out in an autoclave at $121^{\circ} \mathrm{C}$ for 60 minutes, the process was repeated three times to ensure sterility (Castro \& Roa, 2006). 
Germination pots of $6 \mathrm{~cm}$ deep and $4.5 \mathrm{~cm}$ wide were filled at the top with $4.5 \mathrm{~cm}$ of sterile soil. Three seeds (previously treated) were placed per well, as a total of 9 seeds per treatment in each experiment. Later the seeds were covered one $\mathrm{cm}$ with earth; and the plants were watered every day with $5 \mathrm{~mL}$ of sterile distilled water.

At the end of the experiment period (30 days), the plants were uprooted and different growth parameters such as dry weight of root, stem and leaf were measured. The biomass was dried to constant weight in an oven-dried for 4 days at $65^{\circ} \mathrm{C}$. All data were recorded on 10 plants per replicate and the experiment was repeated 3 times. Data were subjected to variance (ANOVA). Significance of $\mathrm{P}<0.05$ was tested by Duncan's multiple range test using the InfoStat statistical software (Version 2016).

\section{Results and Discussion}

The plant promoting traits is in Table 2. Of the 13 isolated, 13 produce siderophores, 11 holds the catalase enzyme and 12 produce the protease enzyme, 10 fixate nitrogen, 12 solubilize phosphorus and 11 produce indoleacetic acid.

As shown in Table 2, 10 isolated are able to fix Nitrogen $(\mathrm{N})$ and 12 are able to solubilize phosphate demonstrated by the color change of culture medium used (data not shown).

Table 2. Biochemical characteristic

\begin{tabular}{|c|c|c|c|c|c|c|}
\hline Strain & $\begin{array}{c}\text { Protease } \\
\text { activity }\end{array}$ & $\begin{array}{l}\text { Catalase } \\
\text { activity }\end{array}$ & $\begin{array}{l}\text { Nitrogen } \\
\text { fixation }\end{array}$ & $\begin{array}{c}\text { Siderophore } \\
\text { production }\end{array}$ & Phosphate solubilization & Production of AIA $(\mu \mathrm{g} / \mathrm{ml})$ \\
\hline Enterobacter sp. AG1 & + & + & + & + & + & 24,53 \\
\hline Stenotrophomona sp. AG 3 & + & + & + & + & + & 24,6 \\
\hline Pseudomona sp. N 24 & + & - & - & + & + & 42,93 \\
\hline Nocardiodes sp. M 1 & - & + & + & + & + & 31,86 \\
\hline Exiguobacterium sp.M 11 & + & + & + & + & + & 16,06 \\
\hline Bacillus sp. TSB 11 & + & + & - & + & + & 42,4 \\
\hline Bacillus sp. TSB 9 & + & + & - & + & + & 60,86 \\
\hline Exiguobacterium sp.S55b & + & + & + & + & + & 3,8 \\
\hline Exiguobacterium sp.S56a & + & + & + & + & + & 10,53 \\
\hline Exiguobacterium sp. S58 & + & + & + & + & - & 34,8 \\
\hline Exiguobacterium sp.S60 & + & + & + & + & + & 1,6 \\
\hline Acinetobacter sp. S68 & + & + & + & + & + & 0 \\
\hline Lactococcus sp. S71 & + & - & + & + & + & 0 \\
\hline
\end{tabular}

Nitrogen is a major nutrient; it has many functions in the growth and development of crop plants. All organisms require $\mathrm{N}$ to synthesize biomolecules such as proteins and nucleic acids. It is also a constituent of compounds as chlorophyll and alkaloids. The nitrogen improves root systems, which has special significance in absorption of water and nutrients (Fageria \& Baligar, 2005). The nitrogen deficiency is the most important nutritional disorder limiting crop yields worldwide. Hence, efficient use of $\mathrm{N}$ in crop production is crucial for increasing crop yield and quality, environmental safety, and economic considerations (Campbell et al., 1995; Grant et al., 2002). The main reserve of nitrogen in the biosphere is molecular nitrogen from the atmosphere. Nevertheless, plants cannot directly assimilate the molecular nitrogen, but it becomes available through the biological nitrogen fixation process "BNF" (Newton, 2000; Franche et al., 2009). Many species of microorganisms are used in the cultivation of plants, facilitating the host plant growth without the use of nitrogenous fertilizers, becoming economic interest. In the case of legumes, there are several nitrogen-fixing microorganisms, such as: Rhizobium, Bradyrhizobium, and Actinomyceto (Paredes, 2013). The production of soybean (Glycine max L.) in Brazil is an excellent example of the efficiency of BNF through the use of different strains of Bradyrhizobium sp., such as B. japonicum and B. elkanii (Alves et al., 2004; Torres et al., 2012). Although we did not work with these genera, our results revealed that Exiguobacterium, Enterobacter, Stenotrophomona, Lactoccocus, and Nocardiales were able to fix nitrogen. The BNF is an important alternative for the recovery of soil fertility, especially now since fertilizer application is an expensive procedure that can also increase contamination (Zahran, 1999).

After Nitrogen, Phosphorus (P) is one of the major essential macronutrients for biological growth and development. It participates as a structural component of nucleic acids, phospholipids and adenosine triphosphate (ATP), as a key element of metabolic and biochemical pathways, particularly important for the BNF and photosynthesis (Khan et al., 2009; Richardson \& Simpson, 2011). Agricultural soils contain large reserves of 
phosphorus, which have been accumulated mostly as a result of regular applications of $\mathrm{P}$ fertilizers. However, a substantial portion of soluble inorganic phosphate in fertilizers is immobilized rapidly in the soil and becomes unavailable to plants (de Souza et al., 2015; Rodríguez \& Fraga 1999).

Phosphate-solubilizing bacteria (PSB) mobilizes insoluble inorganic phosphates from their mineral matrix to the bulk soil where they can be absorbed by the plant roots (Shashidhar \& Podile 2010). Microorganism can transform insoluble phosphates into soluble forms, through the process of acidification, chelation, exchange reactions and the production of gluconic acid (Rodriguez et al., 2004; Chung et al., 2005). Pseudomonas, Rhizobium, Burkholderia, Achromobacter, Agrobacterium, Micrococcus, Aerobacter, Flavobacterium, Acinetobacter, Erwinia and Pantoea have been recognized as the genera of PSB (Rodríguez \& Fraga 1999; Torres et al., 2008; Peix et al., 2009); being Pseudomonas and Bacillus the genera with the greatest potentiality of use in agriculture (Franco, 2015). Among our isolates, only one strain (Exiguobacterium sp. S58) was not able of solubility.

On the other hand, Iron ( $\mathrm{Fe}$ ) is practically one of the essential micronutrients of all living organisms. It is involved in cellular metabolism, as a cofactor of numerous enzymes (Wandersman \& Delepelaire, 2004), and intervenes in various functions of biological processes, such as oxygen transport, DNA synthesis, nitrogen fixation, respiration and photosynthesis (Greenshields et al., 2007); it is also responsible for the green color of plants, fundamentally in the production of chlorophyll (Santacruz et al., 2012). Although it is the fourth most abundant metal in soils, (Crichton \& Charloteaux-Wauters, 1987) in the presence of oxygen and neutral pH (physiological conditions), is inaccessible due to the rapid oxidation of $\mathrm{Fe}^{2+}$ to $\mathrm{Fe}^{3+}$ and the subsequent formation of insoluble hydroxides (Harrington \& Crumbliss, 2009). In conditions of Iron deficiency, the secretion of siderophores by bacteria might stimulate plant growth, thereby improving nutrition through the sequestration of Fe from the environment (de Souza et al., 2015). This positively influences the growth of plants because it allows them to survive in soils with low iron availability, thus improving their conditions. Eleven isolates were positive for siderophore production, showing a yellow zone on CAS- agar medium plate, a Pseudomonas spp. was used as a positive control (data not shown). Although Pseudomonas and Bacillus have been the most studied genera for their ability to produce siderophores, the present study showed that the genera Exiguobacterium, Lactococcus, Enterobacter, Nocardiodes, Acinetobacter and Stenotrophomonas were also able of synthesizing.

Indolic compounds, such as the indole-3-acetic acid (auxin phytohormone) (IAA), present great physiological relevance for bacteria-plant interactions, varying from pathogenesis to phytostimulation (Spaepen et al., 2007). Among plant growth regulators, indole-3-acetic acid (IAA) is the most common natural auxin found in plants, and the $80 \%$ of bacteria is able to produce it (Patten \& Glick 1996; Khalid et al., 2004).; because of its positive effect on root growth and the morphology, is believed that increases the access to more nutrients in the soil (Vessey, 2003); it is also widely used by farmers to accelerate the growth of plants, to promote the initiation of adventitious roots, as well as the flowering, fruit setting and number of leaves (Franco, 2008). Among the most prominent genera are Azospirillum, Azotobacter, Pseudomonas, Rhyzobium and Bacillus among others (Patten \& Glick, 1996). As can be seen in Table 2 Bacillus sp. TSB9 was able to produce the highest concentration of IAA (60.86 $\mu \mathrm{g}$ / $\mathrm{ml}$ ). There are studies carried out on plants of Vigna radiata that demonstrate its high capacity to synthesize this hormone, favoring the elongation of shoots and number of roots (Vega-Celedón et al., 2016).

On the other hand, Exiguobacterium N31 and N24 were also able to produce high concentrations of AIA $54.66 \mu \mathrm{g}$ $/ \mathrm{ml}$ and $42.93 \mu \mathrm{g} / \mathrm{ml}$, respectively. Kasana and Pandey (2017) report Exiguobacterium strains with growth-promoting properties.

Several studies demonstrated that environmental stresses such as drought, salinity, chilling, metal toxicity and UV-B radiation as well as pathogens attack, lead to enhanced generation of reactive oxygen species (ROS) in plants. Extracting or detoxification the excess ROS is achieved by an efficient antioxidative system as the catalase enzyme (Sharma et al., 2012). Our results indicate that all evaluated strains have positive catalase activity.

Finally, protease production was detected in 12 of 13 evaluated strains (data not shown). The microorganisms capable of secreting proteases penetrate plant cells, and in this way influence the colonization of the roots. Furthermore, they also regulate the ecological balance to exercise control over the pathogen and promote the growth of plants due to a bio-control of diseases, nematodes, detoxifying and degrading virulence factors produced by phytopathogens (Velivelli et al., 2015).

The soil sample used for the experiments was silt loam (sand, $10.5 \%$, silt $54.5 \%$ and clay $35 \%$ ), having $\mathrm{pH} 7.30$; electrical conductivity 1,85 [dS /m]; organic matter 8.52\%; C ox 4,26\%, 5,49 [ppm] N-NO ${ }_{3} ; 43,6$ [ppm] P; 47,2 [ppm] S; $0,92[\mathrm{meg} / 100 \mathrm{~g}] \mathrm{Na} ; 1,28[\mathrm{meg} / 100 \mathrm{~g}] \mathrm{K} ; 21[\mathrm{meg} / 100 \mathrm{~g}] \mathrm{Ca} ; 4,5[\mathrm{meg} / 100 \mathrm{~g}] \mathrm{Mg} ; 0,30[\mathrm{meg} / 100 \mathrm{~g}] \mathrm{Na}$ soluble and 1,5 [meg/100g] of Cl. 
The seedlings were grown in a growth chamber with a photoperiod of $16 \mathrm{~h}$ light and $8 \mathrm{~h}$ darkness at $26 \pm 2^{\circ} \mathrm{C}$. After 30 days plant growth shoot, root and leave dry weight were measured.

The effect of inoculation with Exiguobacterium sp. S55b, S56a, S60, S58; Nocardiodes sp. M1 and Lactococcus sp. S71 increased the leaves dry weight; being the highest values obtained in Lactococcus sp. S71 and Exiguobacterium sp. S58. As shown Figure 1, the control has two simple leaves and only two small leaflets, while the plant inoculated with Lactococcus sp. S71 and Exiguobacterium sp. S58 showed a more intense green coloration and greater development (approximately 4 leaflets). These results could be due to the fact that S71 and S58 are capable of fixing Nitrogen, a nutrient that implicates a vigor and abundance of leaves; it is also involved in the synthesis of chlorophyll (Fontanetto and Keller, 2006). However, the soil used had a pH 7.3, the phosphorus which is abundant, in this $\mathrm{pH}$ value may not be bio-available being a limiting factor to the plant growth (Sanchez Lopez, 2014; Fontanetto \& Keller, 2006). For its characteristics Lactococcus sp. S71 would improves the assimilation capacity of phosphorus; this macronutrient is a part of vital biomolecules and fundamental processes for plant development as photosynthesis (Sánchez López, 2014).

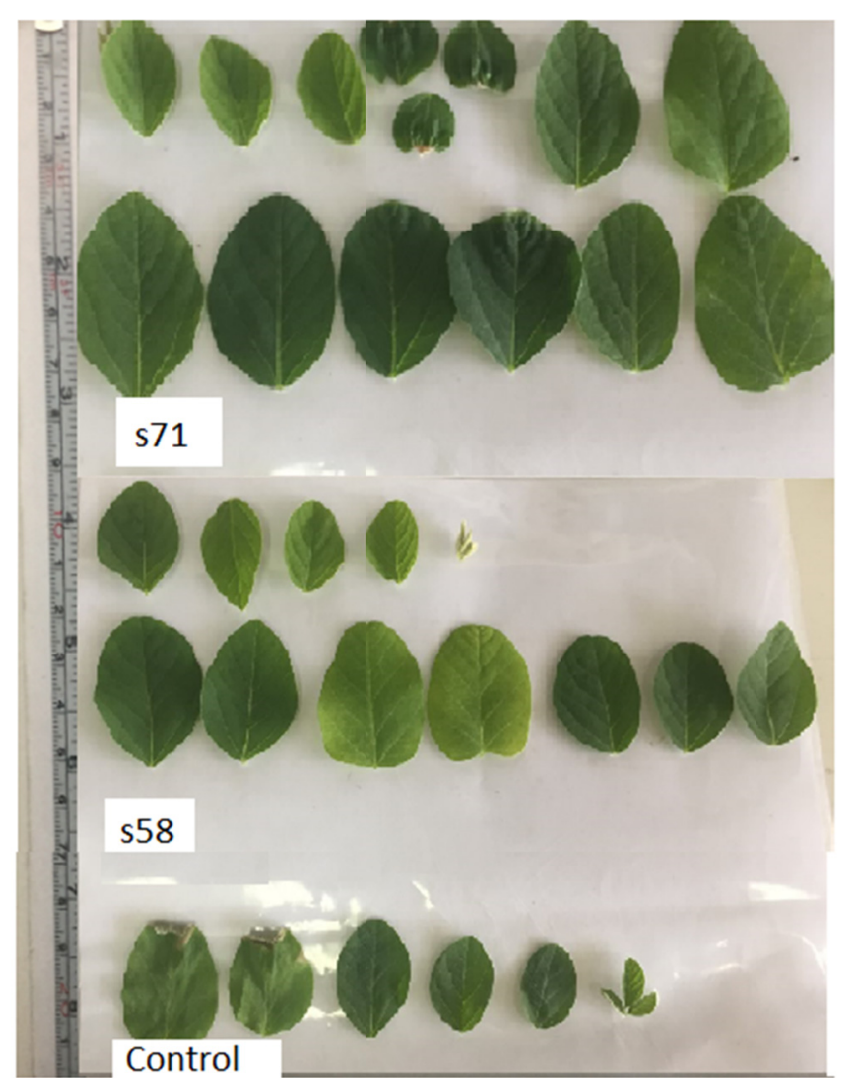

Figure 1. Leaf number of control and treated plant (Exiguobacterium sp. S58 and Lactococcus sp. S71).

With regard to the roots, the increase of the size has an effect on the ability of the plants to assimilate the nutrients of the soil (Antoun \& Prevost, 2005). Our results indicate, the highest values of dry weight correspond to the isolates Nocardioides sp. M1 (2.16 g), Exiguobacterium sp. S58 (2.12g), S55b (2.01) and Lactococcus sp. S71 (2.10) which present highly significant differences with respect to the control $(0.53 \mathrm{~g})$. These values can be associated with Nocardioides sp. M1 and Exiguobacterium sp. S58 to the production capacity of AIA, being 31.86 $\mu \mathrm{g} / \mathrm{ml}$ and $34.8 \mu \mathrm{g} / \mathrm{ml}$, respectively. Indoleacetic acid (IAA) plays a key role in root development (Prusty et al., 2004). Several studies have shown that AIA has an important impact on the root development of plants, because it produces changes in root morphology that induce a greater nutrient acquisition (Loredo-Osti et al., 2004). In case of S71 and S55b the more development observed could be due to other hormones (auxins, gibberellins or cytokines) that can positively influence plant growth, particularly the root system development that were not studied in this work (Figure 2). 


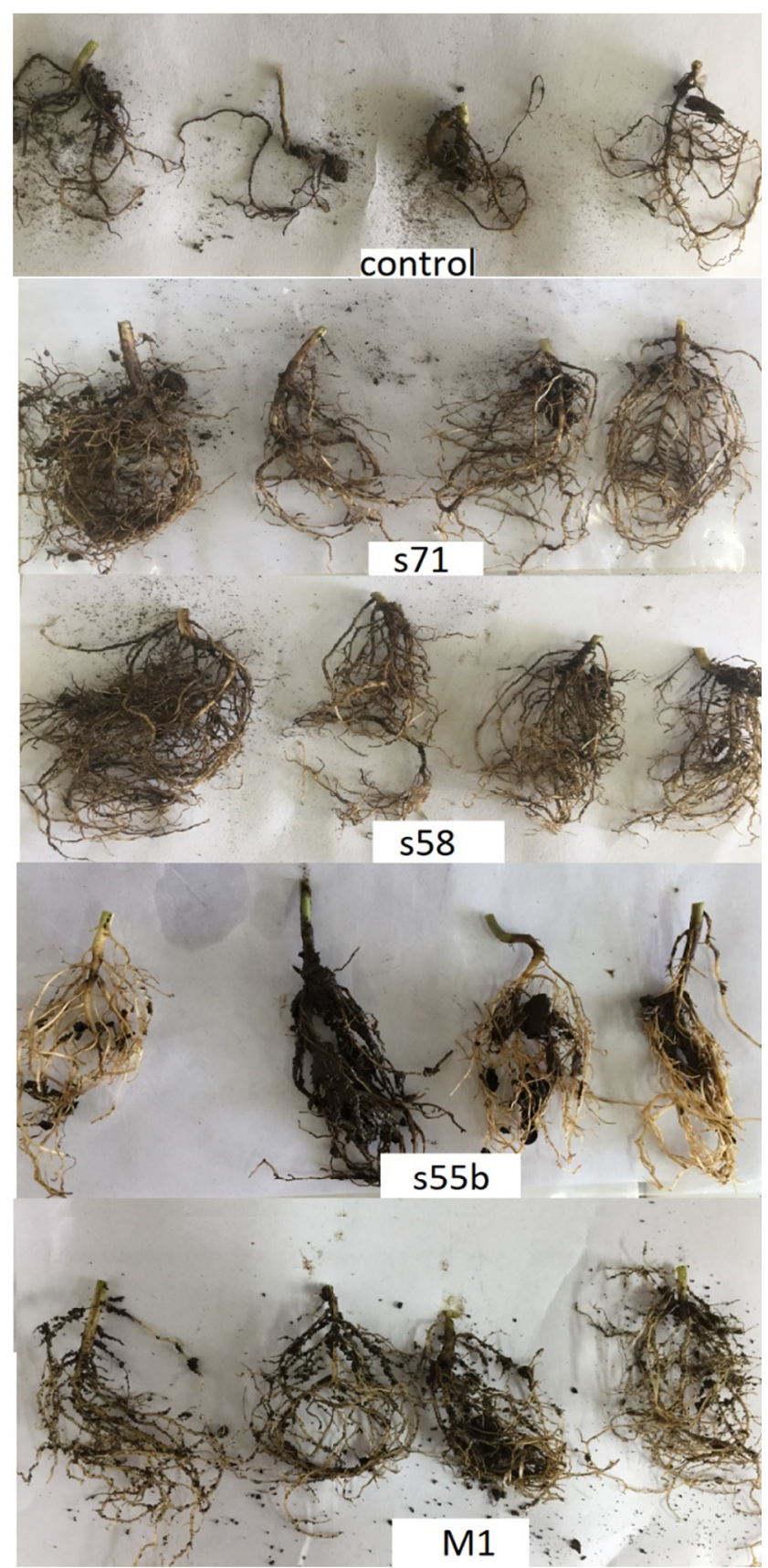

Figure 2. Root length of control and treated plants (Exiguobacterium sp. S58, S55b, M1 and Lactococcus sp. S71)

The results showed that inoculation with bacterial treatments had a more stimulating effect on growth and development of plants. Figure 3, shows the total plant dry weight (root, shoot and leaves). Significant differences were observed of controls (1.61 g) and inoculated plants. Exiguobacterium sp. S58 (6.89 g) and Lactococcus sp. S71 $(6.89 \mathrm{~g})$ showed the highest values. The plants obtained were 5 times higher than the control plants.

In recent years, the use of plant growth promoting bacteria is gaining importance worldwide. With our work, the results showed that all studied strains were able to promote the plant growth. Lactococcus sp. S71 and Exiguobacterium sp. S58 produced plant with a dry weight 5 times higher than the control, with more developed leaves and an intense green coloration and produced the highest root dry weight values, attributed to their ability to synthesize growth stimulating substances. So, these results encourage continuing the studies and considering S58 and $\mathrm{S} 71$ as candidates to formulate a bio-fertilizer as a potential safe ecological alternative. 


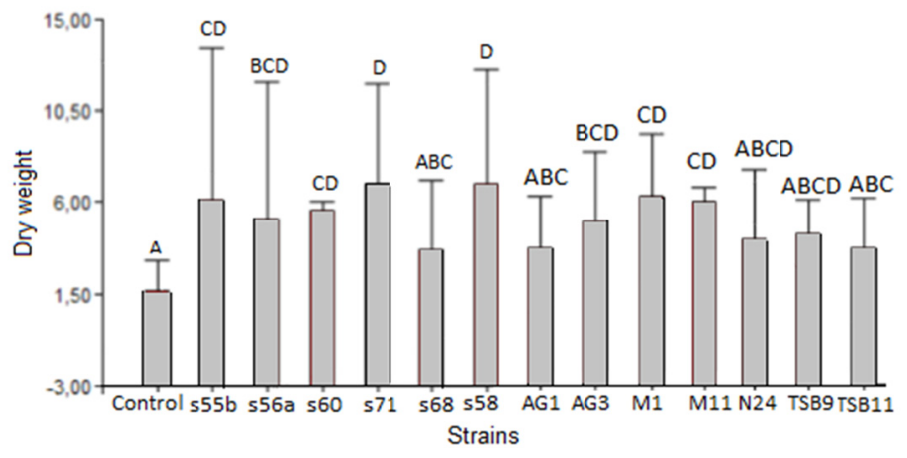

Figure 3. Dry weight of soybean seedling at day 30 after sowing. Data represent mean $\pm \mathrm{SE}$ and different letters above data indicate significant differences among treatments (Test Duncan $\mathrm{p}<0.05$ )

\section{Acknowledgements:}

This work was performed in the context of Project "Análisis de Adaptación al Cambio Climático en Humedales Andinos". ID: 6188775-8-LP13. Ministerio del Medio Ambiente, Región de Antofagasta (www.mma.gob.cl/). The authors are researchers from the National Research Council (CONICET) in Argentina and from the National Universities of Tucumán. They greatly acknowledge the financial support from the PICT V Bicentenario 2010 1788 Project (FONCyT, Argentina).

\section{References}

Abiala, M.A., \& Odebode, A.C. (2015). Rhizospheric Enterobacter enhanced maize seedling health and growth. Biocont. Sci. Technol, 25, 359-372.

Abo-Aba, S.E.M., Soliman, E.A.M., \& Nivien A.A. (2006). Enhanced production of extracellular alkaline protease in Bacillus circulans through plasmid transfer. Res J Agric. Biol Sci, 2, 526-530.

Adesemoye, A., Torbert, H., \& Kloepper, J. (2009). Plant growth- promoting rhizobacteria allow reduced application rates of chemical fertilizers. Microb. Ecol., 58(4), 921- 929.

Ahmad, F., Ahmad, I., \& Saghir, M. (2005). Indole Acetic Acid Production by the Indigenous Isolates of Azotobacter and Fluorescent Pseudomonas in the Presence and Absence of Tryptophan. Turk J Biol., 29, 29-34.

Alves, B.J.R., Boddey, R.M., \& Urquiaga, S. (2004). The success of BNF in soybean in Brazil. Plant Soil, 252, $1-9$.

Antoun, H., \& Prevost. (2005). Ecology of plant growth promoting rhizobacteria. In Z. A. Siddiqui (Ed.), PGPR, Biocontrol and Biofertilization.

Arshad, M., \& Frankenberger, W.T. (1993). Microbial production of plant growth regulators. In B. F. Meeting (Ed.), Soil Microbial Ecology (pp. 307-347). New York: Marcel Dekker.

Berg, G. (2009). Plant-microbe interactions promoting plant growth and health: perspectives for controlled use of microorganisms in agriculture. Appl Microbiol and Biotechnol., 84, 11-18.

Boddey, R.M., \& Döbereiner, J. (1995). Nitrogen fixation associated with grasses and cereals: Recent progress and perspectives for the future. Fertilizer research, 42, 1-3.

Cadena, S., \& Martínez, B. (2011). Caracterización de cepas de Pseudomonas spp. y su efecto en la germinación y emergencia de Zea mays L. "maíz" en Lambayeque. Tesis de Licenciatura. Universidad Nacional Pedro Ruiz Gallo. Lambayeque, Perú

Campbell, C.A., Myers, R.J.K., \& Curtin, D. (1995). Managing nitrogen for sustainable crop production. Fertilizer research, 42, 277-296.

Castro, S., \& Roa, C. (2006). Bacterias endófitas de Cordia alliodora Oken y Tabebuia rosea Bertol D.C: potencial como promotoras de crecimiento vegetal en la propagación de su hospedero. Carrera de Microbiología Agrícola y Veterinaria, Facultad de ciencias, Pontificia Universidad Javeriana, Bogotá. 
Chung, H., Park, M., Madhaiyan, M., Seshadri, S., Song, J., \& Cho, H.S.T. (2005). Isolation and characterization of phosphate solubilizing bacteria from the rhizosphere of crop plants of Korea. Soil Biology and Biochemistry, 37, 1970-1974.

Crichton, R.R., \& Charloteaux-Wauters, M. (1987). Iron transport and storage. The FEBS Journal, 164, 485-506.

De Freitas, J.R., Banerjee, M.R., \& Germida, J.J. (1997). Phosphate-solubilizing rhizobacteria enhance the growth and yield but not phosphorus uotake of canola (Brassica napus L.). Biology and Fertility of Soil, 24, 358-364.

de Souza, R., Ambrosini, A., \& Passaglia, L.M.P. (2015). Plant growth-promoting bacteria as inoculants in agricultural soils. Genetics and Molecular Biology, 38, 401-419.

Fageria, N.K., \& Baligar, V.C., (2005). Enhancing Nitrogen use efficiency in crop plants. Advances in Agronomy, $88,97-185$.

FAO 2016. Argentina cada vez mejor como líder en el mercado mundial de granos y Subproductos. Retrieved from https://www.bcr.com.ar/Pages/Publicaciones/informativosemanal_noticias.aspx?pIdNoticia=3

Fleishman, M.A., Eyal, Z., Zilberstein, A., Voisard, C., \& Haas, D., (1996). Suppression of Septoria tritici blotch and leaf rust of wheat by recombinant cyanide-producing strains of Pseudomonas putida. Mol Plant-Microbe Interact, 9, 642-645.

Fontanetto, H., \& Keller, O., (2006). Consideraciones sobre el manejo de la fertilización de la soja. INTA, Estación Experimental Agropecuaria Rafaela. Información Técnica de cultivos de verano. Campana 2006. Publication Miscellanea N, 106, 45-79.

Franche, C., Lindstrom, K., \& Elmerich, C., (2009). Nitrogen-fixing bacteria associated with leguminous and non-leguminous plants. Plant and Soil, 321, $35-59$.

Franco, M. (2008). Evaluación de caracteres PGPR en Actinomicetos e Interacciones de esta Rizobacterias con hongos Formadores de Micorrizas. Tesis doctoral. Universidad de Granada. España.

García, F.O. (1999). Soja: Criterios para la fertilización del cultivo. INPOFOS/PPI/PPIC Cono Sur. Retrieved from http://www.ipni.net/publication/ia-lacs.nsf/0/3234DEDECFD3B41E85257999005FC651/\$FILE/ FGarcia\%20-\%20Soja\%20CriteriosFertilización.pdf

Gaur, A.C. (1990). Phosphate Solubilizing Microorganisms as Biofertilizers. Omega Scientific Publishers, New Delhi.

Glick, B.R. (2005). Modulation of plant ethylene levels by the bacterial enzyme ACC deaminase. FEMS Microbiol Lett, 252, 1-7.

Grant, A.C., Peterson, G.A., \& Campbell, A.C. (2002). Nutrient Considerations for Diversified Cropping Systems in the Northern Great Plains. Agronomy Journal, 94, 186-198.

Greenshields, D.L., Gousheng, L., \& Wei, Y. (2007). Roles of Iron in Plant Defense and Fungal Virulence. Plant Signal Behav, 2, 300-3002.

Harrington, J.M., \& Crumbliss, A.L. (2009). The redox hypothesis in siderophore-mediated iron uptake. Biometals, 22, 679-689.

Hungria, M., Campo, R.J., Souza, E.M., \& Pedrosa, F.O. (2010). Inoculation with selected strains of Azospirillum brasilense and A. lipoferum improves yields of maize and wheat in Brazil. Plant Soil, 331, 413-425.

Hungria, M., Nogueira, M.A., \& Araujo, R.S. (2013). Co-inoculation of soybeans and common beans with rhizobia and azospirilla: Strategies to improve sustainability. Biol Fertil Soils, 49, 791-801

Kasana, R.C., \& Pandey, C.B. (2017). Exiguobacterium: an overview of a versatile genus with potential in industry and agriculture. Crit Rev Biotechnol, 38, 141-156.

Khalid, A., Tahir, S., Arshad, M., \& Zahir, Z.A. (2004). Relative efficiency of rhizobacteria for auxin biosynthesis in rhizosphere and non-rhizosphere soils. Soil Res, 42, 921-926.

Khan, M.S., Zaidi, A., \& Wani, P.A. (2009). Role of phosphate- solubilizing microorganisms unsustainable agriculture - A review. Agron Sustain Dev, 27, 29-43.

Kloepper, J.W., \& Schroth, M.N. (1978). Plant growth-promoting rhizobacteria on radishes. In: IVth int. Conf Plant Pathogenic Bacteria. Vol: 2 Angers, France.

Lane, D.J. (1991). 16S/23S rRNA sequencing. In E. Stackebrandt \& M. Goodfellow (Eds.), Nucleic acid techniques in bacterial systematics. (pp. 115-175). New York: John Wiley and Sons. 
Loredo-Osti, C., Lopez Reyes, L., \& Espinosa, V.D. (2004). Plant Growth-Promoting Bacteria in Association with Graminaceous Species: A Review. Terra Latinoamericana, 22, 225-239.

Latorre Rapela, M, G., Maumary, R., Marcipar, I., \& Lura, M.C. (2013). Modelo experimental de infeccion de plantas de soja pore species de Cerospora. Rev FABICIB, 17, 66-73.

Louden, B.C., Haarmann, D., \& Lynne, A.M. (2011). Use of Blue Agar CAS Assay for Siderophore Detection. $J$ Microbiol Biol Educ, 12, 51-53.

Newton, W.E. (2000). Nitrogen Fixation. Ecyclopedia of Chemical Technology, 1-51.

Paredes, M.C. (2013). Fijación biológica de nitrógeno en leguminosas y gramíneas. Trabajo Final de Ingeniería en Producción Agropecuaria. Facultad de Ciencias Agrarias. Universidad Católica Argentina. Retrieved from http://bibliotecadigital.uca.edu.ar/repositorio/tesis/fijacion-biologica-nitrogeno-leguminosas.pdf

Pascual, J.A., Hernandez, J., Moreno, L., \& Roset, M. (2000). Soil microbial activity as a biomarker of degradation and remediation processes. Soil Biology and Biochemistry, 32, 1877-1883.

Patten, C.L., \& Glick, B.R. (1996). Bacterial biosynthesis of indole-3-acetic acid. Can J Microbiol, 42, 207-220.

Paul, E., \& Clark, F.E. (1996). Soil microbiology and biochemistry (2nd Ed.). Academic Press, San Diego, California.

Peix, A., Lang, E., Verbarg, S., Spröer, C., Rivas, R., Santa Regina, I., ... Rodriguez-Barrueco, E.V. (2009). Acinetobacter strains IH9 and OCI1, two rhizospheric phosphate solubilizing isolates able to promote plant growth, constitute a new genomovar of Acinetobacter calcoaceticus. Systematic and Applied Microbiology, $32,334-341$.

Pérez-Montaño, F., Alias-Villegas, C., Bellogin, R.A., del Cerro, P., Espuny, M.R., Jimenez-Guerrero, I., Cubo, T. (2014). Plant growth promotion in cereal and leguminous agricultural important plants: From microorganism capacities to crop production. Microbiological Research, 169, 325-336.

Pospiech, A., \& Neumann, B. (1995). A versatile quick-prep of genomic DNA from Gram-positive bacteria. Trends Genet, 11, 217-218.

Prusty, R., Grisafi, P., \& Fink, G.R. (2004). The plant hormone indoleacetic acid induces invasive growth in Saccaromyces cerevisiae. Proc Nati Acad Sci USA, 101, 4153-4157.

Restrepo-Franco, G.M., Marulanda-Moreno, S., de la Fe-Perez, Y., Diaz- de la Osa, A., Baldani, L.V., \& Hernandez-Rodriguez, A. ( 2015). Bacterias solubilizadoras de fosfato y sus potencialidades de uso en la promocion del crecimiento de cultivos de importancia economica. Revista CENIC Ciencias Biológicas, 46, 63-76.

Richardson, A.E., \& Simpson, R.J. (2011). Soil Microorgnisms Mediating Phosphorus Availability Update on Microbial Phosphorus. Plant Physio, 156, 989-996.

Rodríguez, H., \& Fraga, R. (1999). Phosphate solubilizing bacteria and their role in plant growth promotion. Biotechnol Adv, 17, 319-339.

Rodriguez Gonzales, T., Goire, I., \& Bashan, Y. (2004). Gluconic acid production and phosphate solubilization by the plant growth-promoting bacterium Azospirillum spp. Naturwissenschaften, 91, 552-555.

Rothschild, L.J., \& Mancinelli, R.L. (2001). Life in extreme environments. Nature, 1092-101.

Sachden, D.P., Chaidhari, H.G., Kasture, V.M., Dhavale, D.D., \& Chopade, B.A. (2009). Isolation and characterization of indole acetic acid (IAA) producing Klebsiella pneumoniae strains from rhizosphere of wheat (Triticum aestivum) and their effect on plant growth. Indian J Exp Biol, 47, 993-1000.

Sánchez López, D.B. (2014). Efecto de rizobacterias promotoras de crecimiento vegetal solubilizadoras de fosfato en Lactuca sativa cultivar White Boston. Revista Colombiana de Biotecnología, 122-128.

Santacruz, G.A., Moreno-Gómez, B., Jiménez-Francisco, B., García-Moya, E., \& Preciado E. (2012). Impact of the microbial siderophores and phytosyderophores on iron assimilation by plants: A synthesis. Rev Fitotec Mex, 35, 9-21.

Sashidhar, B., \& Podile, A.R. (2010). Mineral phosphate solubilization by rhizosphere bacteria and scope for manipulation of the direct oxidation pathway involving glucose dehydrogenase. J Appl Microbiol, 109, 1-12.

Scher, F.M., \& Baker, R. (1982). Pseudomonas putida and a synthetic iron chelator on induction of soil suppressiveness to Fusarium wilt pathogens. Phytopathology, 72, 1567-1573. 
Shanahan, P., O'Sullivan, D., Simpson, P., Glennon, J., \& O'Gara, F. (1992). Isolation of 2,4-diacetylphloroglucinol from a fluorescent pseudomonad and investigation of physiological parameters influencing its production. Appl Environ Microbiol, 58, 353-358.

Sharma, P., Ambuj, B.J., Rama, S.D., \& Pessarakli, M. (2012). Reactive Oxygen Species, Oxidative Damage, and Antioxidative Defense Mechanism in Plants under Stressful Conditions. Journal of Botany. http://dx.doi.org/10.1155/2012/217037

Spaepen, S., Vanderleyden, J., \& Remans, R. (2007). Indole- 3-acetic acid in microbial and microorganism-plant signaling. FEMS Microbiol Rev, 31, 425-448.

Thakore, Y. (2006). The biopesticide market for global agricultural use. Ind Biotechnol, 2, 194-208

Toledo R. E. (2009). Cultivo de soja. BuscAgro. Retrieved from Http://www.buscagro.com/www.buscagro.com/ biblioteca/Ruben-Toledo/El-cultivo-de-soja.pdf

Torres, A.R., Araujo, W.L., Cursino, L., Hungria, M., Plotegher, F., Mostasso, F.L., \& Azevedo, J.L. (2008). Diversity of endophytic enterobacteria associated with different host plants. Journal of Microbiology, 46, 373-379.

Torres, M.S., White, J.F., Zhang, X., Hinton, D.M., \& Bacon, C.W. (2012). Endophyte-mediated adjustments in host morphology and physiology and effects on host fitness traits in grasses. Fungal Ecol, 5, 322-330.

Vázquez, P., Holguin, G., Puente, E., Lopez-Cortez, A., \& Bashan, Y. (2000). Phosphate-solubilizing microorganisms associated with the rhizosphere of mangroves in semiarid costal lagoon. Biology and Fertility of Soil, 460-468.

Vega-Celedón, P., Canchignia Martinez, H., Gonzalez, M., \& Seeger, M. (2016). Biosynthesis of indole-3-acetic acid and plant growth promoting by bacteria. Cultivos tropicales, 37, 33-39.

Velivelli, S.L.S., Kromann, P., Lojan, P., Rojas, M., Franco, J., Suarez, J.P., \& Prestwich, B.D. (2015). Identificaion of mVOCs from Andean Rhizobacteria and Field Evaluation of Bacterial and Mycorrhizal Inoculants on Growth of Potato un ots Center of Origin. Microbial Ecology, 69, 652-667.

Vessey, K. (2003). Plant growth promoting rhizobacteria as biofertilizers. Plant Soil, 255, 571-586.

Wandersman, C., \& Delepelaire, P. (2004). Bacterial iron sources: from siderophores to hemophores. Annu Rev Microbiol, 58, 611-647.

Zahran, H. H. (1999). Rhizobium-legume symbiosis and nitrogen fixation under severe conditions and in an arid climate. Microbiol Mol Biol Rev, 63, 968-989.

\section{Copyrights}

Copyright for this article is retained by the author(s), with first publication rights granted to the journal.

This is an open-access article distributed under the terms and conditions of the Creative Commons Attribution license (http://creativecommons.org/licenses/by/4.0/). 